\title{
Indigenous Religion in Education and Public Life: Case Study of Permalim and Sunda Wiwitan
}

\author{
Watini \\ Gadjah Mada University, Indonesia
}

\begin{abstract}
The Indonesian government has long recognized six world religions as legitimate ways for its citizens to express their faith in the "one true God" and until recently, has required every person to list one of them on their national identification card. This understanding of religion (agama) leaves little if any space for Indonesia's countless indigenous religions, which both the government and public discourse choose to label using a different term -kepercayaan or beliefs- which marks them as inferior and legitimates discrimination. In recent years, kepercayaaan have been discussed in public, specifically in discourse of regulation No 23 Tahun 2006 tentang Administrasi Kependudukan. It is one of new phenomenon of indigenous religion in Indonesia. This research looks at how indigenous religion is represented in public sphere. In February, MK had been reported that kepercayaan should be noted in ID card based on kepercayaan request. Finally, in November, penghayat kepercayaan's request has been issued by MK. Since this research was standing in religion and public life framework, this research will be focused on how member or kepercayan being perceived by state and the question is how they deal with the policy that their kepercayaan had not been noted in ID card. What are the way that they choose to pursue their purpose to be acknowledged and noted in ID card? My tentative thesis is that they are helped by ANBTI (Aliansi Nasional Binneka Tunggal Ika) so they succeed in pursuing their effort. This is literature research. I see this issue with and relate this issue with theory of hidden transcripts in subcultures because policy in Indonesia strongly use world religion paradigm. The theory which will be used in this research is theory by James scoot in hidden transcript. I collected data by collecting data in e-journal served by Gadjah Mada University and online discussion with Ira Indrawaddy, one of adherent of Sunda Wiwitan in Cigugur. To have more examination I look other case in Permalim. In Permalim case, it is concerned in education teaching. The study of Permalim is supported by film entitled "Ahu Permalim". MK's policy have more role to indigenous religion adherent because it become basic law to them to gain their effort in some problem such as identity card and education.
\end{abstract}

Keywords: Kepercayaan (faith), Indigenous Religion, Public Discourse, Identification Card, Permalim.

\section{Introduction}

In term of Freedom of Religion and Belief, kepercayaan in Indonesia have strong struggle in their live. The word of religion cannot accommodate people who do not have religion or do not belong to official religion that consist of six religions. Another problem is translation of "kepercayaan" as substitute of belief. In reformation era, TAP MPR RI No. VII/MPR/2001 strongly open revitalization discourse of "kepercayaan". Presence and rights of adherent of indigenous religion (penganut agama leluhur) is placed in context of human right discourse. Their rights are discriminated and violated. In old order era, their belief is stated as culture and in new order they are accused as communist and is forced to affiliated into official religion (Maarif, 2017: 73).

"Kepercayan" discourse in reformation era, is also called as "agama leluhur", "agama lokal", "agama asli", agama nusantara" even "kearifan lokal" or local wisdom. In early reformation era, custom issue that is almost lost in public discourse and policy except in custom law, raise again. Community of custom society organized themselves and make Aliansi Masyarakat Adat Nusantara (AMAN) organization. Through AMAN and other 
institution have succeed to influence some policy that belong to masyarakat adat/ community of custom. According to Bagir, human right discourse that can revitalize discourse of indigenous religion also have problem.

Religion as policy, is defined to determine group of nation who have religion or have no religion. Group that is suitable with that definition is supposed as nation and the religion become official religion. group that their religion is rejected particularly indigenous people, their nations is perceived as not legal to be acknowledged, to be protected and to be served.

Indigenous people is nation that their religion is perceived served differently time to time. Their religion is claimed as animism (primitive, pseudo religion) so it should be modernized. Vacating column of religion in civil registration such as in identity card, family card is current development of political religion. although there is development but in fact they still have different treatment from state even have stigma from society that they have no religion. They are perceived as atheism or communism (Maarif, 2017: 2-3).

In reformation era, although the last TAP MPR RI that is TAP MPR RI Nomor VII/MPR/2001 has been admitted kepercayaan (indigenous religion), regulation of Undang-undang Dasar 1945 reveal "revitalization discourse of indigenous (kepercayaan). Indigenous people's right is violated and discriminated (Maarif, 2017: 173).

In the beginning of reformation era, community of adat society organize and make Aliansi Masyarakat Adat Nusantara (AMAN) through their first congress in 1999 in Jakarta. They demand state to fulfill their service because state is careless to serve and treat indigenous society even, state also violated their right (Maarif, 2017:74). One agenda of AMAN is coming back right of tanah ulayat (land for custom society)

Those religious value make contradiction with previous article. As chief of research and development, $\mathrm{M}$. Antho Mudzar said that limitation of indigenous religion is because of manifestation of regulation UU No. 1/PNPS/1965 about defamation of religion (Fauzi, etc in Maarif, 2017: 77).

Lukman Hakim Saifuddin (Minister of Religious Affair) and Patrialis Akbar (ex-lawyer of Mahkamah Konstitusi) said chronologies of including 10 articles that it manages human right in UUD 1945. There is contradiction in 28A-28I because in those articles freedom of religion and belief is reversed with article in $28 \mathrm{~J}$. article 28J with phrase of "religious value" make limitation in chapter 18 article (3) (Bagir, 2014: 28 in Maarif, 2017: 77).

Indonesia has been ratified some regulation of human right. State has been determined UU no. 39/1999 about human right and also has been determined instrument international law of human right. For example, ratification of CERD (UU No. 29/1999), ratification of ICCPR (UU No. 12/2005) and ratification International Covenant of Economic, Social and Cultural Rights (ICESCR) through UU No.11/2005. Even before reformation era, state gas been ratified Convention of the Right of the Child (CRC) through Keppres No. 36/1990 ad Convention on the Elimination of All Forms of Discrimination against Women (CEDAW) that is ratified through UU No. 7/1984. All those instrument is emphasized basic right (Sutanto, 2011: 5 in Maarif, 2017: 78).

Discourse of human right that has been struggled have some problem in their journey. It is against with conservative agenda. Conservative community have some influence with Islamic discourse and even public policy such as local regulation (peraturan daerah/perda) Syariah is some place. Effort to apply human right sometimes crash with other regulation such as UU PNPS 1/1965 particularly in Freedom of Religious and Belief (BAgir, 2014: 29 in (Maarif, 2017, 79).

Indigenous have other problem in struggling of their human right because the regulation of defamation has been asserted by UU No. 16 Tahun 2014 about judiciary. Indigenous religion should be monitored by state. It began after it has been transferred from judiciary into Religious Affair.

Kebatinan and beliefs are present in Java (Kartapradja, 1985: v), Sumatra and Sulawesi, but not all of these streams are officially recorded. Therefore, the government prohibits the flow that is considered will disrupt the stability of society and state. In Indonesia there are several official religions and many schools of kebatinan and belief. To be able to coexist peacefully religious communities and adherents to these streams must have both religious knowledge and outside streams embraced and embraced (Kartapradja, 1985: 60-61). 
Such protection and recognition, he added, is expected to come from the state. The recognition, he argues, is not simply stored in the population database, but is also explicitly acknowledged in official document columns such as family cards and identity cards. The followers of Sunda Wiwitan Dewi Kanti said the empty blanket ID for beliefs is not just a matter of administrative regulation. Yet it is systemic that ultimately legitimizes and perpetuates discrimination. "The pattern of thinkers of the servants' state apparatus, which seems to be just a socialization constraint of a policy. I do not think so, "he said as a witness presented by the applicant. (Humas MK, www.mahkamahkonstitusi.go.id: 2017).

A number of believers argue that Article 61 Paragraphs (1) and Paragraph (2), Article 64 Paragraph (1) and Paragraph (5) of the Population Administration Law are contradictory to the principle of the state of law and the principle of equality of citizens before the law. In his petition, Nggay Mehang Tana, et al., Argued that the KK and the electronic ID card contain elements of religious information in it, but specifically for religious believers the column is emptied so that it is contrary to Article 1 paragraph (3), Article 27 paragraph (1), and Article 28D Paragraph (1) of the 1945 Constitution.

Against such request, in the Legal Considerations read out by Constitutional Justice Saldi Isra, the Court considered the existence of Article 61 and Article 64 of the Population Administration Law aims to realize the orderly administration of population with the establishment of a national population database as well as the validity and validity of the published population documents. Attempts to conduct the orderly administration of population as referred to in the a quo article shall not at all reduce the rights of the citizens concerned, including the right to freedom of religion and belief.

The Constitutional Court (MK) granted all petition for judicial review of Law Number 23 Year 2006 regarding Population Administration as amended by Law Number 24 Year 2013 regarding Population Administration (UU Kependudukan), Tuesday (7/11). Decision Number 97 / PUU-XIV / 2016 read out by the Chief Justice of the Constitutional Court Arief Hidayat accompanied by other constitutional judges (Humas MK, www.mahkamahkonstitusi.go.id: 2017).

\subsection{Hidden Transcript Effort from Sunda Wiwitan and Permalim}

\section{Scott states that}

The public transcript is to put it crudely, the self-portrait of dominant elites as they would have themselves seen. Given the usual power of dominant elites to compel performances from others, the discourse of the public transcript is a decidedly lopsided discussion. While it is unlikely to be merely a skein of lies and misrepresentations, it is on the other hand, a highly partisan and partial narrative. It is designed to be impressive, to afirm and naturalize the power of dominant elites and to conceal or euphemize the dirty linen of their rule.

A second and sharply contrasting form of political discourse is that of the hidden transcript itself. Here, offstage, where subordinates may gather outside the intimidating gaze of power, asharply disonant poitical culture is possible. Slaves in the relative safety of their quarters can speak the words of anger, revenge, selfassertion that ty must normally choke back when in the presence of the masters and mistress (Scott, 1990. 18).

If we look this thoery in case of sunda wiwitan to et their right in $\mathrm{MK}$, it can be categorized that it is effort from hidden transcript in public area. Their problem of administration become problem of public life because they are helped by public transcript such as Aliansi Masyarakat Adat Nusantara (AMAN)) or Aliansi Nasional Bhinneka Tunggal Ika Indonesia (ANBTI).

In this case, kepercayaan may have "stigma" from society and civil servant because adherent of kepercayan cannot gain their right. we can see it in Goffman's theory that there are different intentions behind the use of the word "stigma" for categorizing people, in various contexts. Particularly, women and children have more important to get their right in public life and if the administration to Sunda Wiwitan walk fluently it can empower women in public life because it relate with Kartu Keluarga and Akta Kelahiran.

They see that secularism emphasize women's right but actually secularism oppress woman. As she quoted Asad, Tomalin say that, in common thinking among scholars or development practitioner focus on women's 
rights and empowerment but actually secularism become dangerous and extreme to gender uquality. Second, Tomalin explore to rethink of women's “empowerment,"(Tomalin, 64).

\subsection{Portraying Permalim Case Through Film}

This film described several aspects such as education, religion and social life. Director show us the how permalim adherent get job (money), how permalim adherent worship. Actually, I think this film show us that indigenous religion in Indonesia have developed particularly in public life because it is increased in media. This film portrayed resurgence of Permalim as religion especially in education. in education permalim is taught by teacher but in some place of Indonesia there is no teaching from indigenous religion even indigenous adherent should follow mostly student who belong to world religion such as Islam and Christian.

Seeing this film, I focus in aspects of diversity that is represented on film. This film shows not very limited perspective of diversity in Indonesia but I think this film lack of dialogue from other religion adherent such as Islam and Christianity so audience do not know how relation between them with others because in several scene, there are mentioned just religious teaching divided into three groups, Permalim group, Islam group and Christian group which each of them consist of 12 sudents, 55 students and 1234 students.

We can see that MK's issuing policy support for indigenuos religion teaching in school more open. We can see it also in Java particularly in Central Java. I quoted from one informant:

"In school, she want to fill in book report as kepercayaan but the teacher do not want to write their religion as "kepercayaan". She said that his son may choose, please but firstly she want that his son is in childhood is "kepercayaan".

Nowadays, one informant from other kepercayaan (Pak Wit) said that nowadays kepercayaan adherent have teaching of kepercayaan belief and not other kepercayaan teaching such as islamic teaching or Christian teaching. It still applied in center of his kepercayaan namely in Gombong, Kebumen Central Java.

\section{Conclusion}

We can divide kepercayaan, into two categorization, that is kepercayaan like split from world religion and community reconsidered as "kebijakan lokal" or local wisdom. One of kepercayan is Sunda Wiwitan. As described above, in Sunda Wiwitan case, their struggle to get their effort is can be categorized as hidden transcript in public area because they is helped by public life in huge community. If we see, indigenous religion adherent's strugge as hidden transcript which is helped by publaaic trancript effort make government portrayed here by Mahkamah Konstitusi (MK) moreovor after MK news in Novermber 2017. It is a wind in the desert althought some scholarsh critiicize. At least MK's polic is as basic from government to recognize and implement kepercayaan adherent in gaining their right such as recognition in identity card and education.

\section{Acknowledgements}

This paper is dedicated to persons who help completed this manuscritpt directly and undirectly. I thanks first and foremost my my committee members Dr. Gregory Vanderbilt, Dr. Samsul Maarif. Their tirelesss patience of advicing, encouragement, and insights were invaluable. Both of them have guided me not only on my manuscript but from the beginning of my study at the program.

I would like to also thank the chair of the Indonesia Endowment Fund for Education (LPDP)who help to support this manuscript. I am also thankful to all professors at the department of religious studeis whose supports and inspiration will be always in my mind. My colleagues at PB UGM, MG Jateng, CRCS member 2016, all professor, staff and colleagues in CRCS UGM and UIN Sunan Kalijaga have been also inspiring and helpful. My hosts and many informants have been my "family."

I would never have enough words to express my thanks to my family: my husband and Aini Latidah (my daughter). This work is part of their struggle. It is then dedicated to them. I also dedicate this work to all my brothers. Their praying has been meaningful in my life including especially on this work. I finally dedicate this 
work to my parents, whose spirits ara always in my thoughts and imagination. I hope this work contributes to their lives in the hereafter.

\section{References}

[1] Dwiyanto, Djoko.. Penghayat Kepercayaan terhadap Tuhan Yang Maha Esa di Daerah Istimewa Yogyakarta (Yogyakarta: Pararaton, 2010). (Book Style)

[2] Hasan, Noorhaidi. "The making of public Islam: piety, agency, and commodification on the landscape of the Indonesian public sphere". (Periodical style)

[3] Kartapradja, Kamil. Aliran Kebatinan dan Kepercayaan di Indonesia (Jakarta: Yayasan Masagung, 1985), v.

[4] Muttaqien, Ahmad. "Spiritualitas Agama Lokal". Al-Adyan. Volume. VIII. No. 1. 2013. 89-102. (Journal Online Sources style)

[5] Shelley Tremain, "On the Government of Disability" and Ernest Goffmann, Selections from Stigma (both from L. Davis, ed., Disability Studies Reader. (Periodical style)

[6] Sofwan, Ridin. Menguak Seluk Beluk Aliran Kebatinan (Kepercayaan Terhadap Tuhan Yang Maha Esa) (Semarang: Aneka Ilmu, 1999), hlm. 1.

[7] Rahnip, Aliran Kepercayaan dan Kebatinan dalam Sorotan (Surabaya:Pustaka Progresif, 1997), 27.

[8] Tomalin, Emma . "Gender, Development and the 'Deprivatization of Religion" (Periodical style)

[9] Warner, Michael. "Publics and Counterpublics" (Periodical style) http://www.mahkamahkonstitusi.go.id/index.php?page=web.Berita\&id=13590\#.WJrK9Bt96Mo accessed 8 February 2017. (Institutional Website)

http://www.mahkamahkonstitusi.go.id/index.php?page=web.Berita\&id=14105 $\quad$ accessed 29 November 2017 (Institutional Website)

Interview with Pak Wal, Saturday, 5 Feburary 2018 (Interview with Informant ) 